\title{
The influence of processing and long-term storage on the antioxidant metabolism of acerola (Malpighia emarginata) purée
}

\author{
Luciana S. Oliveira', Maria S. M. Rufino ${ }^{2}$, Carlos F. H. Moura², Fabio R. Cavalcanti ${ }^{3}$, Ricardo E. \\ Alves $^{2}$ and Maria R. A. de Miranda ${ }^{1}$
}

${ }^{1}$ Dept. of Biochemistry and Molecular Biology, Federal University of Ceará, Av. Mr. Hull 2297 BI. 907, Campus do Pici, CEP 60455-760, Fortaleza-CE, Brazil. Tel/Fax. 5585 3366.9826/ 9789F,

2 Embrapa Tropical Agroindustry, R. Dra Sara Mesquita 2270, CEP 60511-110, Fortaleza - CE, Brazil. Tel/Fax: 5585 3391.7201/3391-7101F

${ }^{3}$ Embrapa Grape and Wine, R. Livramento 515, CP 130, CEP 95700-000, Bento Gonçalves- RS, Brazil, Tel/Fax: 55 54 3455.8000/3451.2792F

*Corresponding author: rmiranda@ufc.br, luciana_soy@yahoo.com.br

Received: 24 April 2011; Accepted: 22 July 2011

\section{ABSTRACT}

This study evaluated the effect of the processing and long-term storage on the antioxidant potential and activity of antioxidant enzymes of frozen purées from six acerola clones. Ripe acerolas from clones BRS 235, BRS 236, BRS 237, BRS 238, II47/1 and BRS 152 were harvested; the pulp was processed, packed in sealed polyethylene plastic bags and stored in a domestic freezer at $-18^{\circ} \mathrm{C}$ for 11 months. Samples of each clone were analyzed on harvest/processing day and every 30 days after for bioactive antioxidant compounds, antioxidant enzyme activity and total antioxidant activity. Acerola purées presented a decrease of non-enzyme antioxidants and an increase of antioxidant enzymes activities, indicatives of a compensatory mechanism between enzymatic and non-enzymatic antioxidants. In acerola purée, anthocyanin and polyphenols are strongly correlated to soluble solids content and vitamin $\mathrm{C}$ seems a major contributor to total antioxidant activity. Clone II47/1 had an outstanding performance regarding the antioxidant potential of its purée and the best storage period at $-18^{\circ} \mathrm{C}$ would be 150 days, for all clones studied.

Key words: Pulp, Enzymes, Vitamin C, Postharvest, Frozen

\section{INTRODUCTION}

One of the main problems faced by acerola growers is its very short postharvest life of five days when harvested ripe, leading to a fast decrease of fruit quality which is characterized by significant changes in color, aroma, flavor and mainly texture. The processing of fruits as juices, purées and other products is an alternative use of production surplus and in addition, it enables the integral use of fruits and avoids problems related to seasonality.

Moreover, the processing of fruits aims overall at the aggregation of value and this has been so well accomplished that the market for industrialized fruit products is much larger than the market for 'in natura' fruits (Maia et al., 2007). However, processing and storage of fruit can promote or increase progressive oxidative reactions of enzymatic or 
chemical nature leading to browning of the pulp, undesirable changes in flavor and loss of nutritional value due to degradation of vitamins and fatty acids (Nicoli et al., 1999; Maia et al., 2007).

In plants, external factors as temperature, humidity, light, pathogens and injuries, such as those caused by processing, will induce oxidative stress due to an imbalance between the production of reactive oxygen species (ROS), which may act as stress signals and the ability of components of the antioxidant metabolism to neutralize them (Arora et al., 2002). The same imbalance will occur as part of natural phenomena such as fruit ripening and senescence, when superoxide $\left(\mathrm{O}_{2}^{-}\right)$ and hydrogen peroxide $\left(\mathrm{H}_{2} \mathrm{O}_{2}\right)$ accumulate leading to protein and lipid peroxidation, which may be used as a maturity indicator (Jiménez et al., 2002).

The antioxidant defense system is constituted of a complex array of enzymatic and non-enzymatic compounds which should not be studied individually due to probable synergistic and antagonistic interactions between them. The main antioxidant enzymes are superoxide dismutase (SOD), catalase (CAT) and peroxidases (POX) (Huang et al., 2007). Among the non-enzymatic antioxidants, there are phenolics, ascorbic acid and carotenoids, which act together with the enzymes inhibiting ROS formation or neutralizing them (Hassimotto et al., 2005).

A whole or processed plant organ with high antioxidant capacity presents a great potential for tolerance to the cold (Janda etal., 2002; Leja etal., 2003), for extension of postharvest storage life (Lacan and Baccou, 1998) and for promoting human health benefits associated with their ability to prevent biological degeneration (Seeram and Nair, 2002; Dey and Cederbaum, 2006; Zeashan et al., 2008). Although, in general, processing is responsible for a decrease in the antioxidant capacity and its impact may be evaluated through the activity of enzymes used as damage markers (Miller at al, 1995). However, there have been reports that processing may even improve quality due to an increase in the bioavailability of some antioxidants (Klein and Kurilich, 2000; Kaur and Kapoor, 2001). Up to this date, there is no information about the enzymatic system for active oxygen detoxification in processed acerola.

Storage under freezing temperatures is the most suitable condition for the preservation of chemical, nutritional and sensorial properties of processed fruit as the metabolic reactions are greatly reduced (Yang et al., 2007). However, metabolic reactions are not completely inhibited and undesirable changes in color and flavor of frozen fruit products may still happen, mainly due to the action of enzymes (Howard et al., 2010). Most of the studies investigate the impact of storage conditions for periods shorter than six months, thus, further investigations are necessary to gather pertinent data about quality of fruit products during longer storage periods. This study aimed to evaluate the effect of the processing and longterm storage on the antioxidant potential regarding the activity of antioxidant enzymes of frozen purées from six acerola clones.

\section{MATERIAL AND METHODS}

Fruit and processing: Acerola or West Indian Cherry (Malpighia emarginata D.C) clones BRS 235, BRS 236, BRS 237, BRS 238, II47/1 and BRS 152 selected from a Genetic Improvement Program at Embrapa Tropical Agroindustry (Ceará - Brazil) were used for this study. Red colored ripe fruit were harvested manually at a commercial producing area in the state of Ceará, Brazil. On the same day, the fruit was sanitized with a chlorine solution (50 mg. $\left.\mathrm{L}^{-1}\right)$, processed and the seeds were removed with an industrial extractor; samples of $50 \mathrm{~g}$ were packed and then sealed in polyethylene plastic bags and immediately stored under consumer condition in a domestic freezer at $-18^{\circ} \mathrm{C}$ for 11 months. Samples of each clone were analyzed on harvest/processing day and every 30 days after for bioactive antioxidant compounds, antioxidant enzyme activity and TEAC assay.

Antioxidant enzyme analysis: The acerola purée was lyophilized and samples of $200 \mathrm{mg}$ of powder were homogenized in an ice-cold extraction buffer [100 mM potassium-phosphate buffer $(\mathrm{pH} 7.0)+0.1 \mathrm{mM}$ EDTA]. The homogenate was filtered through a muslin cloth and centrifuged at $12,000 \mathrm{~g}$ for $15 \mathrm{~min}$. The supernatant fraction was used as a crude extract for enzyme activity assays and all the procedures above were performed at $4^{\circ} \mathrm{C}$. The total protein content was determined according to Bradford (1976).

Superoxide dismutase (SOD, EC 1.15.1.1) activity was determined spectrophotometrically based on inhibition of the photochemical reduction of nitroblue tetrazolium chloride (NBT, Sigma) (Giannopolitis and Ries, 1977). The reaction mixture (1.5 ml) contained $50 \mathrm{mM}$ phosphate buffer ( $\mathrm{pH} 7.8$ ), $0.1 \mathrm{mM}$ EDTA, $13.5 \mathrm{mM}$ methionine, $75 \mathrm{mM}$ NBT, $10 \mu \mathrm{M}$ 
riboflavin and the reaction was initiated with $50 \mu \mathrm{l}$ enzyme extract in the presence of light, under two $20 \mathrm{~W}$ fluorescent lamps for $15 \mathrm{~min}$, after which the lights were switched off. The reaction mixture absorbance was measured by the Spectronic Genesys Spectrophotometer at $560 \mathrm{~nm}$ and one unit of SOD activity (UA) was defined as the amount of enzyme required to cause a $50 \%$ reduction in the NBT photo-reduction rate. Thus, results were expressed as UA. $\mathrm{mg}^{-1} \mathrm{P}$ (protein).

Catalase (CAT, EC 1.11.1.6) activity was measured according to Beers and Sizer (1952). The reaction mixture $(1.5 \mathrm{ml})$ consisted of $100 \mathrm{mM}$ phosphate buffer (pH 7.0), EDTA, $0.5 \mathrm{M}$ and $37.5 \mu \mathrm{l}$ enzyme extract. The reaction was started by adding the enzyme extract, the decrease in $\mathrm{H}_{2} \mathrm{O}_{2}$ (Merck) was monitored through absorbance at $240 \mathrm{~nm}$ and quantified by its molar extinction coefficient $\left(36 \mathrm{M}^{-1} \mathrm{~cm}^{-1}\right)$. The results were expressed as $\mu \mathrm{mol} \mathrm{H}_{2} \mathrm{O}_{2} \cdot \mathrm{mg}^{-1} \mathrm{P}$. $\mathrm{min}^{-1}$.

Ascorbate peroxidase (APX, EC 1.11.1.1) activity was assayed according to Nakano and Asada (1981). The reaction mixture $(1.5 \mathrm{ml})$ constituted of $50 \mathrm{mM}$ phosphate buffer $(\mathrm{pH}$ 6.0), $0.05 \mathrm{mM}$ EDTA, $0.015 \mathrm{mM}$ ascorbic acid (Merck), $0.03 \mathrm{mM} \mathrm{H}_{2} \mathrm{O}_{2}$ and $50 \mu \mathrm{l}$ enzyme extract. The reaction was started by adding ascorbic acid and ascorbate oxidation was measured through absorbance at $290 \mathrm{~nm}$. Enzyme activity was measured using the molar extinction coefficient for ascorbate $\left(2.8 \mathrm{mM} . \mathrm{cm}^{-1}\right)$ and the results expressed in $\mu$ mol $\mathrm{H}_{2} \mathrm{O}_{2} \cdot \mathrm{mg}^{-1} \mathrm{P}$. min ${ }^{-1}$, taking into account that 1 mols of ascorbate are required for a reduction of $1 \mathrm{~mol} \mathrm{H}_{2} \mathrm{O}_{2}$.

Non-enzymatic antioxidants: The total phenolic content of acerola purée was measured by a colorimetric assay using Folin-Ciocalteu reagent (Sigma) as described by Obanda and Owuor (1997). Before the colorimetric assay, the samples were subjected to a procedure of extraction in $50 \%$ methanol and $70 \%$ acetone as described by Larrauri et al. (1997). For the colorimetric assay, $1 \mathrm{~mL}$ of Folin Ciocalteau (1:3) reagent, $2 \mathrm{~mL} \mathrm{Na}_{2} \mathrm{CO}_{3}$ at $20 \%$ and $2.850 \mathrm{~mL}$ of distilled water were added to $150 \mu \mathrm{L}$ of extract. After incubation in the dark for 30 min, absorbance was measured at $700 \mathrm{~nm}$, gallic acid (Acros Organics) was used as the standard and results were expressed as galic acid equivalents (GAE) mg. $100 \mathrm{~g}^{-1} \mathrm{FW}$ (fresh weight).

Anthocyanins and yellow flavonoids were extracted and determined as described by Francis (1982). One gram of purée was extracted with a 95\% ethanol / $1.5 \mathrm{~N} \mathrm{HCl}(85: 15)$ solution, vortexed for 2 minutes and then, brought to $50 \mathrm{~mL}$ with the extracting solution. Protected from the light, the mixture was refrigerated at $4^{\circ} \mathrm{C}$ for 12 hours, then filtered on Whatman N.1 paper and the filtrate was gathered. The absorbance of the filtrate was measured at $535 \mathrm{~nm}$ for the total anthocyanin content using an absorption coefficient of 98.2 and at $374 \mathrm{~nm}$ for the total yellow flavonoid content using an absorption coefficient of 76.6, both results were expressed as $\mathrm{mg} .100 \mathrm{~g}^{-1} \mathrm{FW}$.

The total vitamin $\mathrm{C}$ was determined by titration with Tillman solution (0.02\% 2,6 dichloro-indophenol, DFI from Sigma) described by Strohecker and Henning (1967). One gram of purée was diluted to to $100 \mathrm{~mL}$ of $0.5 \%$ oxalic acid and then homogenized. Then $5 \mathrm{~mL}$ of this solution was taken and added to distilled water at the level of $50 \mathrm{~mL}$ and tirated, thus results were expressed as $\mathrm{mg} .100 \mathrm{~g}^{-1} \mathrm{FW}$.

Total antioxidant activity by TEAC assay: The total antioxidant activity (TAA) was determined using ABTS method as described by Re et al. (1999) which measures the ability of lipophilic and hydrophilic antioxidants to quench a 2,2'-azinobis 3-ethylbenzthiazoline-6-sulphonic acid (ABTS ${ }^{*}$, Sigma) radical cation. The radical solution was formed using $7 \mathrm{mM}$ $\mathrm{ABTS}^{*+}$ and $140 \mathrm{mM}$ potassium persulfate, incubated and protected from light for $16 \mathrm{~h}$. Absorbance at $734 \mathrm{~nm}$ was measured (results close to 0.700 ) to check $\mathrm{ABTS}^{*+}$ formation. Once the radical was formed, the reaction was started by adding $30 \mu \mathrm{L}$ of extract in $3 \mathrm{~mL}$ of radical solution, absorbance was measured (734 nm) after 6 min and the decrease in absorption was used to calculate the total antioxidant activity (TAA). A calibration curve was prepared and different Trolox (Sigma) concentrations (standard trolox solutions ranging from 100 to $2000 \mu \mathrm{M}$ ) were also evaluated against the radical. Antioxidant activity was expressed as Trolox equivalent antioxidant capacity (TEAC), $\mu$ mol Trolox.$g^{-1}$ FW.

Data analysis: The experiment was conducted as $6 \mathrm{x}$ 12 factorial design with treatments defined as acerola clones (BRS 235, BRS 236, BRS 237, BRS 238, $1147 / 1$ and BRS $152)$ and time in storage $(0,30,60,90,120,150,180,210$, $240,270,300$ and 330 days). The experimental parcels were made up of three repetitions consisting of a $50 \mathrm{~g}$ package each. Statistical analyses consisted of data being subjected to analysis of variance (ANOVA) with SISVAR statistical software and significant differences were determined by either Student's or Tukey's test, at 5\% significance level. 


\section{RESULTS AND DISCUSSION}

Non-enzymatic antioxidants and their potential: The evaluated antioxidant components and total antioxidant activity of acerola purées showed a relative stability throughout the storage trial, thus only data for the harvesting/processing day, 150 and 300 days are given (Table 1).

Table 1. Long-term influence of cold storage on bioactive compounds and total antioxidant activity (ABTS) of acerola clones purée.

\begin{tabular}{|c|c|c|c|c|c|c|}
\hline \multirow{2}{*}{ Clone $^{1}$} & \multirow{2}{*}{$\mathrm{DAH}^{2}$} & Anthocyanin $^{3}$ & Total Vitamin C & Flavonoids & ABTS $^{4}$ & Polyphenols \\
\hline & & $\mathrm{mg} \mathrm{100 \textrm {g } ^ { - 1 } \mathrm { FW }}$ & $10^{2}{\mathrm{mg} 100 \mathrm{~g}^{-1} \mathrm{FW}}$ & $\mathrm{mg} 100 \mathrm{~g}^{-1} \mathrm{FW}$ & $\mu \mathrm{mol}$ Trolox g ${ }^{-1} \mathrm{FW}$ & $10^{1}{\mathrm{mg} 100 \mathrm{~g}^{-1} \mathrm{FW}}$ \\
\hline \multirow{3}{*}{ BRS 238} & 0 & $19.95 \pm 6.26 \mathrm{Ba}$ & $16.67 \pm 0,78 \mathrm{Aa}$ & $14.73 \pm 6.81 \mathrm{ABa}$ & 122.77 & $22.37 \pm 3.12 \mathrm{Aa}$ \\
\hline & 150 & $9.19 \pm 0.60 \mathrm{Bb}$ & $11.58 \pm 0.10 \mathrm{Ac}$ & $9.22 \pm 3.86 \mathrm{Aab}$ & 84.1 & $17.66 \pm 0.32 \mathrm{Ab}$ \\
\hline & 300 & $9.44 \pm 1.05 \mathrm{Bb}$ & $14.07 \pm 0.24 \mathrm{ABb}$ & $6.06 \pm 0.59 \mathrm{Ab}$ & 52.37 & $17.77 \pm 1.62 \mathrm{Ab}$ \\
\hline \multirow{3}{*}{ II 47/1 } & 0 & $35.28 \pm 1.65 \mathrm{Aa}$ & $16.53 \pm 0.19 \mathrm{Aa}$ & $20.50 \pm 2.78 \mathrm{Aa}$ & 115.47 & $18.72 \pm 1.15 \mathrm{Ba}$ \\
\hline & 150 & $16.68 \pm 0.71 \mathrm{Ab}$ & $10.29 \pm 0.31 \mathrm{Bb}$ & $8.97 \pm 0.79 A b$ & 86.71 & $17.14 \pm 0.49 \mathrm{Aa}$ \\
\hline & 300 & $13.72 \pm 0.81 \mathrm{Ab}$ & $10.16 \pm 0.47 \mathrm{Cb}$ & $10.10 \pm 0.50 \mathrm{Ab}$ & 58.51 & $16.69 \pm 0.46 \mathrm{ABa}$ \\
\hline \multirow{3}{*}{ BRS 235} & 0 & $12.36 \pm 1.37 \mathrm{Ca}$ & $11.37 \pm 0.05 \mathrm{Da}$ & $7.59 \pm 1.52 \mathrm{Ca}$ & 63.69 & $18.98 \pm 0.67 \mathrm{Ba}$ \\
\hline & 150 & $9.23 \pm 0.69 \mathrm{Bab}$ & $7.65 \pm 0.26 \mathrm{Cc}$ & $8.35 \pm 2.19 \mathrm{Aa}$ & 59.57 & $13.05 \pm 0.08 \mathrm{Bb}$ \\
\hline & 300 & $7.28 \pm 0.32 \mathrm{Bb}$ & $9.56 \pm 0.66 \mathrm{Cb}$ & $7.59 \pm 0.17 \mathrm{Aa}$ & 58.44 & $13.62 \pm 0.46 \mathrm{BCb}$ \\
\hline \multirow{3}{*}{ BRS 152} & 0 & $5.75 \pm 1.55 \mathrm{Da}$ & $15.45 \pm 0.24 \mathrm{Ba}$ & $6.91 \pm 4.77 \mathrm{Ca}$ & 109.11 & $22.98 \pm 0.96 \mathrm{Aa}$ \\
\hline & 150 & $3.87 \pm 0.26 \mathrm{Ca}$ & $10.95 \pm 0.10 \mathrm{ABC}$ & $6.14 \pm 1.62 \mathrm{Aa}$ & 75.75 & $17.70 \pm 0.59 \mathrm{Ab}$ \\
\hline & 300 & $3.70 \pm 0.54 \mathrm{Ca}$ & $13.86 \pm 0.26 \mathrm{Bb}$ & $5.53 \pm 0.98 \mathrm{Aa}$ & 58.44 & $17.69 \pm 3.33 \mathrm{Ab}$ \\
\hline \multirow{3}{*}{ BRS 237} & 0 & $12.07 \pm 0.92 \mathrm{Ca}$ & $12.41 \pm 0.30 \mathrm{Ca}$ & $8.05 \pm 1.56 \mathrm{BCa}$ & 70.54 & $13.96 \pm 0.41 \mathrm{Ca}$ \\
\hline & 150 & $8.28 \pm 0.17 \mathrm{Bb}$ & $8.27 \pm 0.37 \mathrm{Cc}$ & $9.14 \pm 5.54 \mathrm{Aa}$ & 74.89 & $12.03 \pm 0.26 \mathrm{Ba}$ \\
\hline & 300 & $7.99 \pm 0.54 \mathrm{Bb}$ & $9.58 \pm 0.24 \mathrm{Cb}$ & $7.59 \pm 0.37 \mathrm{Aa}$ & 77.12 & $12.97 \pm 0.58 \mathrm{Ca}$ \\
\hline \multirow{3}{*}{ BRS 236} & 0 & $10.42 \pm 0.28 \mathrm{Ca}$ & $16.64 \pm 0.30 \mathrm{Aa}$ & $7.92 \pm 0.40 \mathrm{BCa}$ & 104.53 & $11.30 \pm 0.52 \mathrm{Cb}$ \\
\hline & 150 & $8.34 \pm 0.07 \mathrm{Ba}$ & $10.70 \pm 0.22 \mathrm{ABC}$ & $8.13 \pm 1.30 \mathrm{Aa}$ & 75.52 & $18.12 \pm 0.51 \mathrm{Aa}$ \\
\hline & 300 & $9.10 \pm 0.44 \mathrm{Ba}$ & $14.87 \pm 0.25 \mathrm{Ab}$ & $8.07 \pm 0.76 \mathrm{Aa}$ & 52.23 & $19.49 \pm 2.67 \mathrm{Aa}$ \\
\hline $\mathbf{F}_{0.05}$ & & 108.47 & 266.46 & 6.9 & - & 30.05 \\
\hline
\end{tabular}

${ }^{1}$ Pulps were stored at $-18^{\circ} \mathrm{C}$ in a cold chamber for 12 months.

${ }^{2} \mathrm{DAH}=$ days after harvest.

${ }^{3}$ Within clones, values, values with same capital letters at the same date not significantly different at $\rho>0.05$ according Tukey's test. Between days after harvest $(\mathrm{DAH})$ in each clone, values with same small letters are not significantly different at $\rho>0.05$ according Tukey's test.

${ }^{4}$ Replicates were composed in a single sample according Re et al. (1999).

The polyphenol contents remained constant for clones II 47/1 and BRS 237, meanwhile clones BRS 238, 152 and 235 showed a significant decrease at 150 days of storage $(P \geq 0.05)$, in spite of this decrease, clones BRS 238 and 152 maintained the greatest contents during storage. On harvest/processing day, clone BRS 152 presented over $50 \%$ more polyphenol than BRS 236 , although this difference decreased through storage as clone BRS 236 showed a completely different behavior and increased its polyphenol content over storage. This increased could be explained by the formation of Maillard reaction products which are capable of reacting with FolinCiocalteu's reagent or to a plain release of polyphenols from purée matrix as a consequence of time, as suggested by Garcia-Alonso et al. (2009). The polyphenols contents of the acerola purées varied from 750 to $1490 \mathrm{mg} \mathrm{GAE}$. $100 \mathrm{~g}^{-1} \mathrm{FW}$ and were high when compared to tomato juice (26-30 mg GAE. $100 \mathrm{~g}^{-1}$ FW) (Garcia-Alonso et al, 2009) and to dehydrated noni purée, $200 \mathrm{mg}$ GAE. $100 \mathrm{~g}^{-1}$ (Yang et al., 2007). 
The greatest reductions in anthocyanin contents were observed at 150 days of storage, except for purées from clones BRS 236 and 152 which showed no significant changes during storage $(P \geq 0.05)$. The initial anthocyanin content varied from 35 to $5 \mathrm{mg}$. $100 \mathrm{~g}^{-1} \mathrm{FW}$ and the greatest loss was observed for clone $\| 47 / 1$, over $60 \%$, although it still maintained the highest levels during storage. The loss of anthocyanin may be explained by ROS oxidation and subsequent formation of anthocyanin-procyanindin (another phenolic) polymers or conversion of anthocyanins into chalcones, which spontaneously degrade into phenolics and this instability of anthocyanin may be directly associated to the type of sugar attached rather than aglycon structure (Ruenroengklin et al., 2009; Howard et al., 2010). Brito et al. (2007) evaluated fruits from the same acerola varieties studied here and observed that cyanidin 3-rhamnoside and pelargonidin 3-rhamnoside were the major anthocyanins and that their content was cultivar-dependent, as for clones $1147 / 1$ and BRS 237 the cyanidin content was 359 and $169 \mathrm{mg} .100$ $\mathrm{g}^{-1}$ dry weight (DW) and pelargonidin content was 181 and $80 \mathrm{mg} .100 \mathrm{~g}^{-1} \mathrm{DW}$, respectively. A study showed blueberries have much higher anthocyanin content $\left(594.7 \mathrm{mg}^{100 \mathrm{~g}^{-1}}\right.$ FW) than those found here for acerola and that processing and storage at $4{ }^{\circ} \mathrm{C}$ for six months resulted in greater than 50\% retention (Howard et al., 2010).

Flavonoids are characterized by the flavan nucleus and present a radical scavenging activity (TEAC) twice as much as that of vitamin $E$ (Heim et al., 2002). The yellow flavonoids contents of the acerola purées were mostly stable during storage and varied from 5.5 to $20.5 \mathrm{mg}$. $100 \mathrm{~g}^{-1} \mathrm{FW}$. On harvest day, clones BRS 238 and $1147 / 1$ had the highest values and were the only ones to present a decrease after 150 days of storage, reaching the same levels $(P>0.05)$ as the other clones. In tomato juice, the flavonoid content remained constant over 12 months of storage and was not influenced by temperatures ranging from 8 to $37^{\circ} \mathrm{C}$ (Garcia-Alonso et al., 2009).

The clones with the highest contents, II 47/1 and BRS 238 , showed the greatest decrease in anthocyanin and yellow flavonoids after 120 and 90 days after harvest, respectively. Meanwhile, the flavonoid and anthocyanin contents of BRS 235 , clone with the lowest content, did not differ significantly at the same period of storage. When the two most contrasting clones II 47/1 and BRS 235 are compared, the same behavior is obvious in spite of the different concentrations and the greatest changes in both anthocyanin and yellow flavonoid contents occurred up to 150 days of storage (Figure $1 \mathrm{~A}$ and $1 \mathrm{~B}$, respectively), although there were no changes in polyphenol content associated (Table 1).
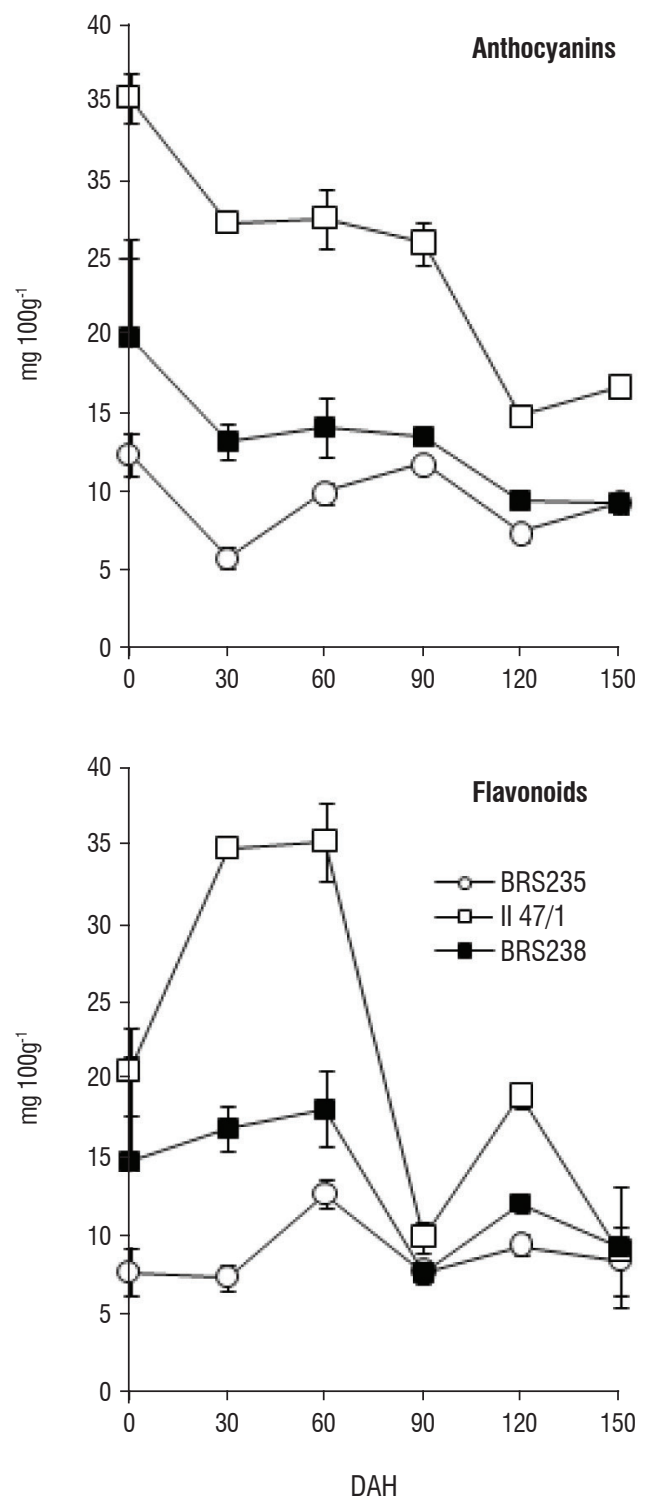

Figure 1. Early (A) anthocyanin and (B) flavonoid profiles at $-18^{\circ} \mathrm{C}$ storage in BRS 235 (-o-), II 47/1 (- $\square-)$ and BRS 238 (--) acerola clones purée. Responses were evaluated $0,30,60,90,120$ and 150 days after harvesting (DAH). Error bars indicate standard deviation.

The total vitamin C content of acerola purées decreased after 150 days and then increased again at the end of the storage period for the clones evaluated, except II47/1 which remained constant. At harvest, clones BRS 
238, BRS 236 and II 47/1 had the highest vitamin C contents $\left(1,667,1,664\right.$ and $1,653 \mathrm{mg} .100 \mathrm{FW} \mathrm{g}^{-1}$, respectively, $P>0.05)$ and at the end of the trial, clones BRS 236 and 238 still had the highest values, 1,487 and 1,407 mg. 100 $\mathrm{g}^{-1}$, respectively. The greatest total vitamin C loss was observed for clone II47/1, 39\% over 10 months of storage and it could be explained by auto-oxidation, degradation by condensation due to high levels of anthocyanin or by oxidation by enzymes as ascorbate oxidase and peroxidase (Yahia et al., 2001). There is controversial data on the association between phenolics and vitamin C stability, for Miller and Rice-Evans (1997) reported that phenolics protected vitamin C from degradation, meanwhile Rosso and Mercadante (2007) implied that anthocyanin would condensate with ascorbic acid leading to a faster degradation of both compounds. Cultivars, agricultural practices, storage time and temperature also have great influence on vitamin $\mathrm{C}$ concentration during postharvest (Caris-Veyrat et al., 2004; Serpen et al., 2007; GarciaAlonso et al., 2009).

Vitamin C consists of two forms, ascorbic acid and dehydroascorbic acid which are in a reversible equilibrium, although dehydroascorbic acid may also be irreversibly oxidized to 2,3-diketoglutonic acid. When peas were stored under freezing $\left(-18^{\circ} \mathrm{C}\right)$ conditions for 12 months, there was a $91 \%$ loss of ascorbic acid and an estimated half-life of 3.12 months (Serpen et al., 2007). These authors reported that blanching increased the ascorbic acid half-life to 99.7 months and in order to retain vitamin $C$ of processed vegetables, the key point is to limit the hydrolysis of dehydroascorbic acid into 2,3-diketoglutonic acid, thus the loss of vitamin C during storage depends on the balance of oxidation and reduction capacities. In spite of the loss during storage, the total vitamin $\mathrm{C}$ contents of the acerola purées studied were still much higher than for most commercialized fruit as apple cv. Gala pulp (not detected), tomato (17.5 mg. FW $100 \mathrm{~g}^{-1}$ ), banana (18.6 mg. FW $100 \mathrm{~g}^{-1}$ ), pineapple (22 mg. FW $\left.100 \mathrm{~g}^{-1}\right)$, star fruit (37.4 mg. FW $\left.100 \mathrm{~g}^{-1}\right)$, red guava pulp (56 mg. FW $100 \mathrm{~g}^{-1}$ ), lemon (74 mg. FW 100 $\mathrm{g}^{-1}$ ), orange pulp (83 $\mathrm{mg}$. FW $100 \mathrm{~g}^{-1}$ ) and persimmon (210 mg. FW $100 \mathrm{~g}^{-1}$ ) (Lee and Kader, 2000; Caris-Veyrat et al., 2004; Hassimotto et al., 2005).
At harvest, the total antioxidant activity (TAA) measured as the ability to neutralize $\mathrm{ABTS}^{+}$and determined as Trolox equivalent antioxidant capacity (TEAC) was greater in clones BRS 238, II 47/1, BRS 152 and 236 with 122, 115, 109 and $104 \mu \mathrm{mol}$ Trolox. $\mathrm{g}^{-1} \mathrm{FW}$, respectively and decreased over $50 \%$ during storage. Meanwhile, clones BRS 237 and 235 had lower initial TEAC levels, 70 and $63 \mu$ mol Trolox. $\mathrm{g}^{-1} \mathrm{FW}$, which remained virtually unchanged and all clones reached similar levels at the end of storage. Purée from clones BRS 238 and II 47/1 had the greatest TEAC and also the highest anthocyanin, vitamin C, flavonoid and polyphenol contents, meanwhile clones BRS 237 and 235 with the lowest TEAC values had also the lowest vitamin $C$ content, indicating that vitamin $\mathrm{C}$ is a major contributor to acerola purée antioxidant capacity.

The variability of antioxidant activity found here may be influenced by the genetic potential of each cultivar as it is by agricultural practices, ripening stage and storage conditions (Murcia et al., 2009). Compared to the acerola purées studied here, the TEAC of tomato juice with added vitamin $\mathrm{C}$ was higher, $200 \mu \mathrm{mol}$ Trolox $\mathrm{g}^{-1}$ FW and decreased $30 \%$ over a 12 month-storage at $8^{\circ} \mathrm{C}$ (Garcia-Alonso et al., 2009). These authors reported that ascorbic acid and phenolics were the main contributors to TAA, and moreover, the TAA of the hydrophilic fraction of the tomato extract was $84 \%$ greater than for the lipophilic fraction. For noni juice, the phenolics exhibited a significant correlation to TAA, which was quite stable under freezing conditions $\left(-18^{\circ} \mathrm{C}\right)$ for three months (Yang et al., 2007). For blueberries, anthocyanins are the major contributors for TAA and processing results in a decrease in anthocyanin content due to complexation with other phenolics or formation of Maillard reaction products, however, these latter are potent antioxidants and may contribute to increase in TAA (Howard et al., 2010).

Antioxidant enzymes: The main postharvest preservation method for fruit quality is storage under freezing temperatures, as the metabolic reactions are greatly reduced, although they are not completely inhibited mainly due to the action of enzymes (Howard et al., 2010). As the evaluated antioxidant components, the activity of the antioxidant enzymes showed a relative stability through out the storage trial, thus only data for acerola purées at harvesting/processing day, 150 and 300 days are given (Table 2). 
Table 2. Long-term influence of cold storage on superoxide dismutase (SOD), catalase (CAT) and ascorbate peroxidise (APX) activities of acerola clones purée.

\begin{tabular}{|c|c|c|c|c|}
\hline & & $\operatorname{SOD}^{3}$ & CAT & APX \\
\hline clone $^{1}$ & DAH $^{2}$ & $102 \mathrm{UA}(\mathrm{mgP})^{-1}$ & $\mu \mathrm{mol} \mathrm{H}_{2} \mathrm{O}_{2}(\mathrm{mgP} \min )^{-1}$ & $10^{-1} \mu \mathrm{mol} \mathrm{H} \mathrm{O}_{2}(\mathrm{mgP} \mathrm{min})^{-1}$ \\
\hline \multirow[t]{3}{*}{ BRS 238} & 0 & $2.62 \pm 0.04 \mathrm{Ac}$ & $38.97 \pm 6.01 \mathrm{Ba}$ & $3.43 \pm 0.39 \mathrm{Ba}$ \\
\hline & 150 & $69.97 \pm 1.35 \mathrm{Ba}$ & $23.87 \pm 8.86 \mathrm{CDb}$ & $1.96 \pm 1.07 \mathrm{ABb}$ \\
\hline & 300 & $46.65 \pm 1.96 \mathrm{Cb}$ & $3.42 \pm 0.38 \mathrm{Cc}$ & $4.13 \pm 0.02 \mathrm{Ba}$ \\
\hline \multirow[t]{3}{*}{ \|| 47/1 } & 0 & $0.88 \pm 0.02 \mathrm{Ac}$ & $8.28 \pm 3.37 \mathrm{Cc}$ & $1.87 \pm 0.16 \mathrm{Cb}$ \\
\hline & 150 & $76.49 \pm 0.57 \mathrm{Aa}$ & $43.19 \pm 13.56 \mathrm{ABb}$ & $1.67 \pm 0.22 \mathrm{ABb}$ \\
\hline & 300 & $65.36 \pm 1.79 \mathrm{Ab}$ & $91.56 \pm 0.83 \mathrm{Aa}$ & $6.00 \pm 0.43 \mathrm{Aa}$ \\
\hline \multirow[t]{3}{*}{ BRS 235} & 0 & $1.50 \pm 0.04 \mathrm{Ac}$ & $14.34 \pm 0.86 \mathrm{Cb}$ & $3.90 \pm 0.58 \mathrm{Ba}$ \\
\hline & 150 & $68.00 \pm 0.23 \mathrm{BCa}$ & $56.46 \pm 15.24 \mathrm{Aa}$ & $2.37 \pm 0.50 \mathrm{Ab}$ \\
\hline & 300 & $42.19 \pm 1.12 \mathrm{Db}$ & $11.77 \pm 0.33 \mathrm{Cb}$ & $4.06 \pm 0.14 \mathrm{Ba}$ \\
\hline \multirow[t]{3}{*}{ BRS 152} & 0 & $4.15 \pm 0.07 \mathrm{Ab}$ & $137.73 \pm 9.72 \mathrm{Aa}$ & $6.80 \pm 1.01 \mathrm{Aa}$ \\
\hline & 150 & $64.43 \pm 3,00 \mathrm{Ca}$ & $38.58 \pm 8.54 \mathrm{BCC}$ & $1.63 \pm 0.04 \mathrm{ABb}$ \\
\hline & 300 & $67.23 \pm 1.10 \mathrm{Aa}$ & $59.01 \pm 9.97 \mathrm{Bb}$ & $6.83 \pm 0.31 \mathrm{Aa}$ \\
\hline \multirow[t]{3}{*}{ BRS 237} & 0 & $0.75 \pm 0.01 \mathrm{Ac}$ & $3.91 \pm 1.15 \mathrm{Ca}$ & $2.01 \pm 0.20 \mathrm{Cb}$ \\
\hline & 150 & $43.37 \pm 0.58 \mathrm{Ea}$ & $16.27 \pm 3.00 \mathrm{Da}$ & $1.60 \pm 0.71 \mathrm{ABb}$ \\
\hline & 300 & $31.56 \pm 0.35 \mathrm{~Eb}$ & $7.91 \pm 0.27 \mathrm{Ca}$ & $3.70 \pm 0.03 \mathrm{Ba}$ \\
\hline \multirow[t]{3}{*}{ BRS 236} & 0 & $1.37 \pm 0.01 \mathrm{Ac}$ & $14.87 \pm 0.51 \mathrm{Cb}$ & $1.97 \pm 0.31 \mathrm{Cb}$ \\
\hline & 150 & $52.53 \pm 2.71 \mathrm{Db}$ & $26.27 \pm 1.75 \mathrm{BCDb}$ & $1.17 \pm 0.32 \mathrm{Bb}$ \\
\hline & 300 & $56.90 \pm 5.77 \mathrm{Ba}$ & $77.46 \pm 5.48 \mathrm{Aa}$ & $6.10 \pm 0.22 \mathrm{Aa}$ \\
\hline $\mathrm{F}_{0.05}$ & & 172.79 & 110.35 & 31.64 \\
\hline
\end{tabular}

${ }^{1}$ Pulps were stored at $-18^{\circ} \mathrm{C}$ in a cold chamber for 12 months.

${ }^{2} \mathrm{DAH}=$ days after harvest.

${ }^{3}$ Within clones, values with same capital letters at the same date are not significantly different at $\rho>0.05$ according Tukey's test. Between days after harvest (DAH) in each clone, values with same small letters are not significantly different at $\rho>0.05$ according Tukey's test.

SOD catalyses the breakdown of $\mathrm{O}^{2-}$ to $\mathrm{O}_{2}$ and $\mathrm{H}_{2} \mathrm{O}_{2}$ and has been implicated as an essential defense against the potential toxicity of oxygen (Jiao and Wang, 2000). At harvest, the SOD activity was lower with no statistical differences among the clones ranging from 75 to 415 UA.mg $\mathrm{P}^{-1}$, however during storage, clone II 47/1 presented the greatest values, meanwhile clone BRS 237 had the lowest $(P>0.05)$. The SOD activity increased during storage reaching the highest levels at 150 days for the clones evaluated, except for clone BRS 236 which increased until the end of storage, ranging from 3156 to
6723 UA.mg $\mathrm{P}^{-1}$. The increase in SOD activity could be a response to an stress induced by long-term freezing storage and the activities values found for acerola clone purées were much higher than those reported for juice of different blackberry cultivars, 8 to 13 UA.mg $\mathrm{P}^{-1}$ and for different orange cultivars, 43 to 73 UA.mg P-1 (Jiao and Wang, 2000; Huang et al., 2007). SOD activity was positively correlated $(r=0.90)$ to the TAA of blackberry juice (Jiao and Wang, 2000), but this seems to not be the case for acerola purées here studied. 
Table 3. Pearson correlation coefficients of antioxidant parameters versus soluble solids content of the two most contrasting acerola clones after a 330 days storage interval.

\section{Correlation Coefficients}

\begin{tabular}{|c|c|c|}
\hline \multirow[t]{2}{*}{ Parameters ${ }^{1}$} & \multicolumn{2}{|c|}{ SS $\left({ }^{\circ} \text { Brix }\right)^{2}$} \\
\hline & \| 47/1 & BRS 235 \\
\hline Anthocyanins (mg $100 \mathrm{~g}^{-1} \mathrm{FW}$ ) & 0.648 & 0.022 \\
\hline Ascorbate (mg $\left.100 \mathrm{~g}^{-1} \mathrm{FW}\right)$ & 0.84 & -0.166 \\
\hline Polyphenols (mg 100 $\mathrm{g}^{-1} \mathrm{FW}$ ) & 0.558 & 0.293 \\
\hline ABTS $(\mu$ mol Trolox g-1 FW) & 0.688 & -0.594 \\
\hline Flavonols (mg $100 \mathrm{~g}^{-1} \mathrm{FW}$ ) & 0.606 & -0.502 \\
\hline SOD $\left(\mathrm{UA}(\mathrm{mgP})^{-1}\right)$ & -0.043 & -0.047 \\
\hline APX $\left(\mu \mathrm{mol} \mathrm{H}_{2} \mathrm{O}_{2}(\mathrm{mgP} \mathrm{min})^{-1}\right)$ & -0.334 & 0.401 \\
\hline CAT $\left(\mu \mathrm{mol} \mathrm{H} \mathrm{H}_{2} \mathrm{O}_{2}(\mathrm{mgP} \mathrm{min})^{-1}\right)$ & -0.527 & 0.179 \\
\hline
\end{tabular}

${ }^{1}$ Antioxidant properties were evaluated at 0, 30, 60, 90, 120, 150, 180, 210, $240,270,300$ and 330 days after harvest.

${ }^{2}$ Soluble solids (SS) vs Parameters.

CAT is responsible for scavenging $\mathrm{H}_{2} \mathrm{O}_{2}$ (Janda et al., 2002). The CAT activity was highest at harvest for clone BRS 152 purée $\left(1.37 \mu \mathrm{mol} \mathrm{H}_{2} \mathrm{O}_{2} \cdot \mathrm{mg} \mathrm{P}^{-1}\right.$. $\left.\mathrm{min}^{-1}\right)$ and then decreased during storage, as did clone BRS 238. Clone BRS 237 presented very low and constant activity levels during storage, meanwhile clones II47/1 and BRS 236 increased their CAT activity reaching the highest levels at the end of storage to 0.9 and $0.7 \mu \mathrm{mol} \mathrm{H}_{2} \mathrm{O}_{2} \cdot \mathrm{mg} \mathrm{P}^{-1} \cdot \mathrm{min}^{-1}$, respectively. The acerola clones showed very low CAT activities and different sensitivities to freezing. Juice from six different blackberry clones did not show any CAT activity (Jiao and Wang, 2000) and ripe fruit from three orange clones showed very low CAT activity (Huang et al., 2007).

On harvest/processing day, clone BRS 152 and 235 had the highest APX activities $\left(0.34\right.$ and $0.19 \mu \mathrm{mol} \mathrm{H}_{2} \mathrm{O}_{2}$. $\mathrm{mg} \mathrm{P}^{-1} \cdot \mathrm{min}^{-1}$, respectively). Clones BRS 238, 235 and 152 showed a decrease in APX activity after 150 days and then, an increase, meanwhile clones II47/1, BRS 237 and 236 presented only an increase at the end of storage. Thus, all the clones evaluated showed higher APX activity at the end of storage ranging from 0.18 to $0.34 \mu \mathrm{mol} \mathrm{H}_{2} \mathrm{O}_{2}$. $\mathrm{mg} \mathrm{P}^{-1}$. min $^{-}$ 1. The increase in APX activity could be a response to an oxidative stress induced by long-term freezing storage, as Janda et al. (2002) found a high correlation between APX activity and frost tolerance in cereals. The increase in APX activity during acerola purée storage may also be associated to vitamin $\mathrm{C}$ decay and in a lesser extent to polyphenol degradation (Table 1). Oms-Oliu et al. (2008) reported that processing of 'Piel de sapo' melons resulted in an increase in peroxidase (POD) activity and in vitamin $\mathrm{C}$ oxidation and related this to a greater affinity of melon POD for ascorbic acid over guaiacol as a substrate. In blackberry juice, APX was positively correlated to both ascorbic acid and to TAA (Jiao and Wang, 2000).

Table 3 shows the correlation of enzymatic and nonenzymatic antioxidants and soluble solids (SS, data not shown) of the two clones with the most distinct behaviors, $\| 47 / 1$ and BRS 235. The SS content is an important quality parameter and it was positively correlated to anthocyanin and polyphenols for both clones, while vitamin $\mathrm{C}$ was only positively associated to the SS content in clone $\| 47 / 1$, although with a high correlation coefficient. In the acerola clone II47/1 purée, the TAA was highly correlated to SS as were all the non-enzymatic antioxidants evaluated, although the antioxidant enzymes were negatively correlated, specially CAT. In the acerola clone BRS 235 purée, TAA was negatively highly associated to SS content as were vitamin $C$ and flavonoids. Meanwhile, the antioxidant enzymes APX and CAT were positively correlated. These results indicate that anthocyanin and polyphenols are major contributors to SS content and suggest that vitamin $\mathrm{C}$ is a major contributor to TAA, in acerola purée.

A comparison of antioxidant parameters between these two contrasting acerola clones II 47/1 and BRS 235 indicate, although with no significant statistical differences, there is a compensatory mechanism between enzymatic and nonenzymatic antioxidants in acerolas, those clones with lower levels of antioxidants compounds and TAA will depend more on the antioxidant activity of enzymes, especially on APX (Figure 2). 


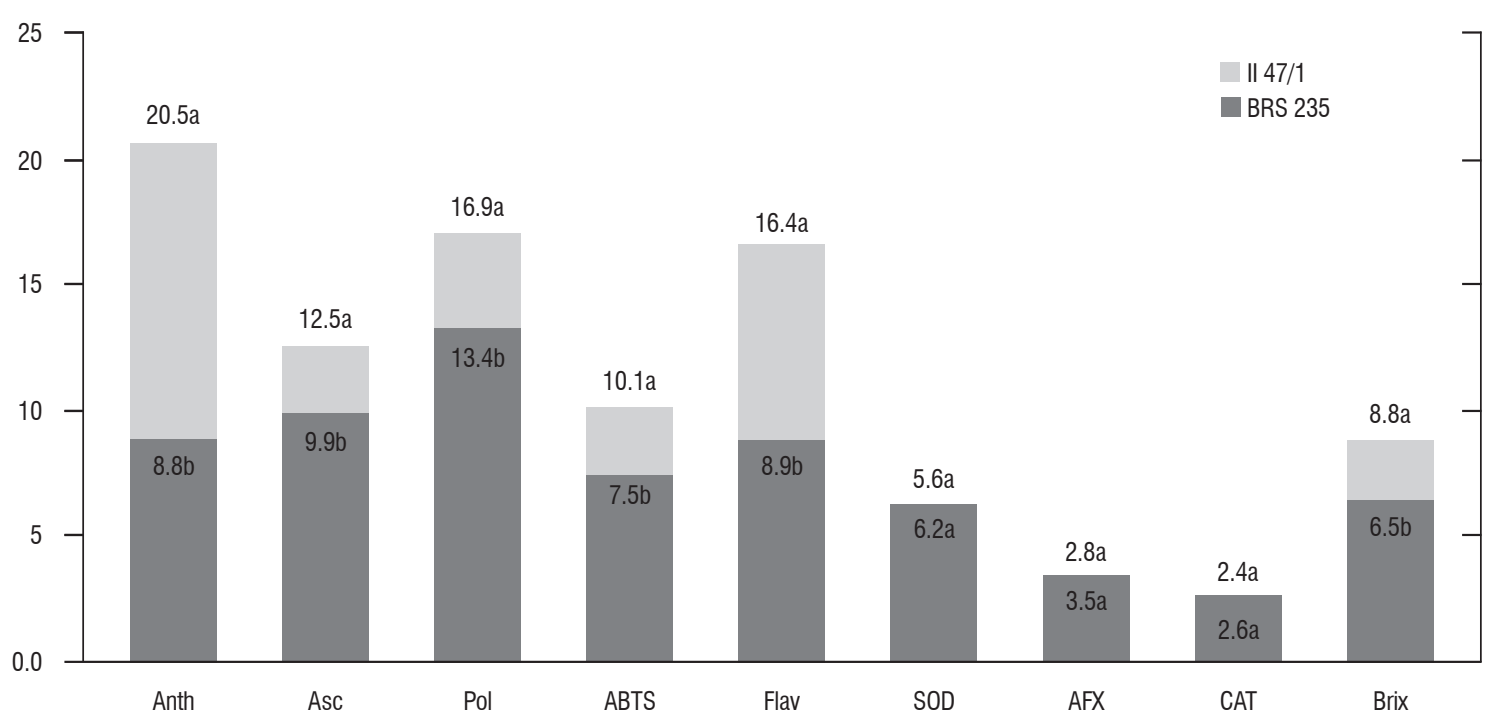

Figure 2. Comparison of antioxidant properties between the two most contrasting acerola clones II 47/1 and BRS 235 as means of monthly evaluation were

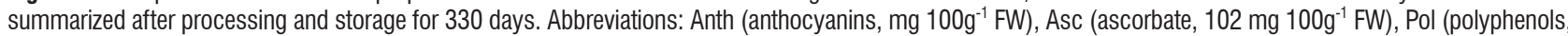

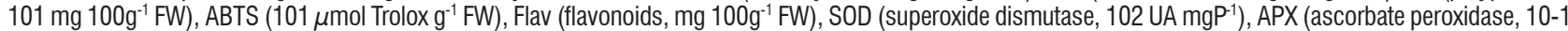
$\mu \mathrm{mol} \mathrm{H}_{2} \mathrm{O}_{2} \mathrm{mgP}^{-1} \mathrm{~min}^{-1}$ ), CAT (catalase, $101 \mu \mathrm{mol} \mathrm{H} 202 \mathrm{mgP}^{-1} \mathrm{~min}^{-1}$ ), Brix (soluble solids, ${ }^{\circ}$ Brix). Values with the same small letters denote no significant differences at $\rho>0.05$ according Student's t-test.

These results show that purée from acerola clones BRS $235,236,237,238$ and II47/1 have great antioxidant potential thus, a considerable capacity for free-radical scavenging. Anthocyanin and polyphenols are strongly correlated to SS content and vitamin $\mathrm{C}$ seems to be a major contributor to TAA, in acerola purée. Acerola purées presented a decrease of non-enzyme antioxidants and in general, an increase of antioxidant enzymes activities which may be a consequence of an oxidative stress due to long-term storage under freezing temperatures. There are also signs of a compensatory mechanism between enzymatic and non-enzymatic antioxidants in acerolas, those clones with lower levels of antioxidants compounds and TAA will depend more on the antioxidant activity of enzymes, especially on APX. Among the clones studied, II 47/1 had an outstanding performance regarding the antioxidant potential of its purée and the best storage period at $-18^{\circ} \mathrm{C}$ would be 150 days, for most of the acerola clones studied.

Acknowledgements: This work was supported by FUNCAP (Fundação Cearense de Apoio ao Desenvolvimento Científico e Tecnológico), INCT-Frutos Tropicais/CNPq (Conselho Nacional de Desenvolvimento Científico e
Tecnológico) and CAPES (Coordenação de Aperfeiçoamento de Pessoal de Nível Superior), Brazil..

\section{REFERENCES}

Arora, A., Sairam, R.K., Srivastava, G.C. (2002). Oxidative stress and antioxidative system in plants. Curr. Sci, 82, 1221-1235.

Beers-Jr R.F., Sizer I.W. (1952) A spectrophotometric method for measuring the breakdown of hydrogen peroxide by catalase. J. Biol. Chem, 195, 133140.

Bradford, M.M. (1976) A rapid and sensitive method for the quantification of microgram quantities of protein utilizing the principle of protein-dye binding. Anal. Biochem, 722, 248-254.

Brito, E.S., Araujo, M.C.P., Alves, R.A., Carkeet, C., Clevidence, B.A., Novotny, J.A. (2007) Anthocyanins present in selected tropical fruits: acerola, jambolão, jussara and guajiru. J. Agric. Food Chem, 55, 9389-9394.

Caris-Veyrat, C., Amiot, M.J., Tyssandier, V., Grasselly, D., Buret, M., Mikolajczak, M., Guilland, J.C., Bouteloup-Demange, C., Borel, P. (2004). Influence of organic versus conventional agricultural practice on the antioxidant microconstituent content of tomatoes and derived purees: Consequences on antioxidant plasma status in humans. J. Agric. Food Chem, 52 (21), 6503-6509.

Dey, A., Cederbaum, A.I. (2006). Alcohol and oxidative liver injury. Hepatology, 43(2), 63-74.

Francis, F.J. (1982) Analysis of anthocyanins. In: Markakis, P. (Ed.) Anthocyanins as food colors (pp. 181-207). New York: Academic Press.

Garcia-Alonso, F.J., Bravo, S., Casas, J., Perez-Conesa, D., Jacob, K., Periago, M.J. (2009) Changes in antioxidant compounds during the shelf life of commercial tomato juices in different packaging materials. J. Agric. Food Chem, 57(15), 6815-6822. 
Giannopolitis, C.N., Ries, S.K. (1977) Superoxide dismutase. I. Occurrence in higher plants. Plant Physiol., 59, 309-314.

Howard, L.R., Castrodale, C., Brownmiller, C., Mauromoustakos, A. (2010). Jam processing and storage effects on blueberry polyphenolics and antioxidant capacity. J. Agric. Food Chem, 58, 4022-4029.

Hassimotto, N.M.A., Genovese, M.I., Lajolo, F.M. (2005) Antioxidant activity of dietary fruits, vegetables and commercial frozen fruit pulps. J. Agric. Food Chem, 53, 2928-2935.

Heim, K.E., Tagliaferro, A.R., Bobilya, D.J. (2002). Flavonoid antioxidants: chemistry, metabolism and structure-activity relationships. J. Nutr. Biochem, 13(10), 572-584.

Huang, R., Xia, R., Hu, L., Lu, Y., Wang, M. (2007). Antioxidant activity and oxygen-scavenging system in orange pulp during fruit ripening and maturation. Sci. Hortic, 113, 166-172.

Janda, T., Szalai, G., Rios-Gonzalez, K., Veisz, 0., Páldi, E. (2002). Correlation between frost tolerance and antioxidant activities in cereals. Acta Biol. Szegediensis, 46(3-4), 67-69.

Jiao, H., Wan, S.Y. (2000) Correlation of antioxidant capacities to oxygen radical scavenging enzyme activities in blackberry. J. Agric. Food Chem, 48, 5672-5676.

Jiménez, A., Creissen, G., Kular, B., Firmin, J., Robinson, S., Verhoeyen, M. Mullineaux, P. (2002) Changes in oxidative processes and components of the antioxidant system during tomato fruit ripening. Planta, 214, 751-758.

Kaur, C., Kapoor, H.C. (2001). Antioxidants in fruits and vegetables - the millennium's health. Int. J. Food Sci. Technol, 36, 703-725.

Klein, B.P., Kurilich, A.C. (2000). Processing effects on dietary antioxidants from plant food. HortScience, 35, 580-584.

Lacan, D., Baccou, J. (1998) High levels of antioxidant enzymes correlate with delayed senescence in nonnetted muskmelon fruits. Planta, 204, 377382.

Larrauri, J.A, Rupérez, P., Saura-Calixto, F. (1997) Effect of drying temperature on the stability of polyphenols and antioxidant activity of red grape pomace peels. J. Agric. Food Chem, 45, 1390-1393.

Lee, S.K., Kader, A.A. (2000). Preharvest and postharvest factors influencing vitamin C content of horticultural crops. Postharvest Biol. Technol., 20(3), 207-220.

Leja, M., Mareczek, A., Ben, J. (2003) Antioxidant properties of two apple cultivars during long-term storage. Food Chem, 80, 303-307.

Maia, G.A., Sousa, P.H.M., Santos, G.M., Silva, D.S., Fernandes, A.G., Prado, G.M. The effect of processing on components of acerola juice. Ciência e Tecnologia de Alimentos, 27, 130-134.

Miller, N.J., Diplock, A.T., Rice-Evans, C.A. (1995). Evaluation of the total antioxidant activity as a markeer of deteriotration of apple juice on storage. J. Agric. Food Chem, 43, 1794-1801.
Miller, N.J., Rice-Evans, C.A. (1997). The relative contributions of ascorbic acid and phenolic antioxidants to the total antioxidants to the activity of orange and apple fruit juices and black currant drink. Food Chem, 60: 331-337.

Murcia, M., Jimenez, A.M., Martinez-Tome, M. (2009). Vegetables antioxidant losses during industrial processing and refrigerated storage. Food Res. Int, 42: 1046-1052.

Nakano, Y., Asada, K. (1981) Hydrogen peroxide is scavenged by ascorbatespecific peroxidases in spinach chloroplast. Plant Cell Physiol, 22, 867-880.

Nicoli, M.C., Anese, M., Parpinel, M. (1999) Influence of processing on the antioxidant properties of fruits and vegetables. Food Sci. Technol, 10, 94-100.

Obanda, M., Owuor, P.O. (1997) Flavonol composition and caffeine content of green leaf as quality potential indicators of Kenyan black teas. J. Sci. Food Agric, 74, 209-215.

Oms-Oliu, G., Odriola-Serrano, I., Soliva-Fortuny, R., Martin-Belloso, 0. (2008) The role of peroxidase on the antioxidant potential of fresh-cut 'Piel de sapo' melon packaged under different modified atmosphere. Food Chem, 106, 1085-1092.

Re, R., Pellegrini, N., Proteggente, A., Pannala, A., Yang, M., Rice-Evans, C. (1999) Antioxidant activity applying an improved ABTS radical cation decolorization assay. Free Radical Biol. Med, 26 (9/10), 1231-1237.

Rosso, V.V., Mercadante, A.Z. (2007) The high ascorbic acid content is the main cause of the low stability of anthocyanin extracts from acerola. Food Chem, 103, 935-943.

Ruenroengklin, N.; Yang, B., Lin, H., Chen, F., Jiang, Y. (2009). Degradation of anthocyanin from litchi fruit pericarp by $\mathrm{H}_{2} \mathrm{O}_{2}$ and hydroxyl radical. Food Chem, 116(4), 995-998.

Seeram, N.P., Nair, M.G. (2002) Inhibition of lipid peroxidation and structure-activity-related studies of the dietary constituents anthocyanins, anthocyanidins, and catechins. J. Agric. Food Chem, 50 (19), 5308-5312.

Serpen, A., Gokmen, V., Bahçeci, K.S, Acar, J. (2007) reversible degradation kinetics of vitamin $C$ in peas during frozen storage. Eur. Food Res. Technol, $224,749-753$.

Strohecker, R., Henning, H.M. (1967) Analisis de vitaminas: métodos comprobados. (428p) Madrid: Paz Montalvo.

Yahia, E.M., Conteras-Padilla, M., Gonzalez-Aguiar, G. (2001). Ascorbic acid content in relation to ascorbic acid oxidase activity and polyamine content in tomato and bell pepper fruits during development, maturation and senescence. Lebensm.-Wiss. Technol, 34: 452-457.

Yang, J., Paulino, R., Janke-Stedronsky, S., Abawi, F. (2007) Free-radicalscavenging activity and total phenos of noni (Morinda citrifolia) juice and powder in processing and storage. Food Chem. 102, 302-308.

Zeashan, H., Amresh, G., Singh, S., Rao, C. V. (2008). Hepatoprotective activity of Amaranthus spinosus in experimental animals. Food Chem. Toxicol, 46(11), 3417-3421. 